Año XLVIII. urtea

$122-2016$

Uztaila - abendua

Julio - diciembre

Sor की:

sus

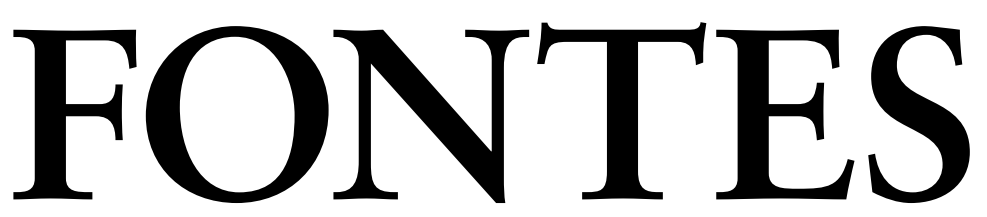

LINGVÆ

VASCONVM

STVDIA ET DOCVMENTA

SEPARATA

\title{
An introduction to
}

Basque aspiration: the contribution of

\section{onomastics}

Patxi Salaberri Zaratiegi, Iker Salaberri Izko

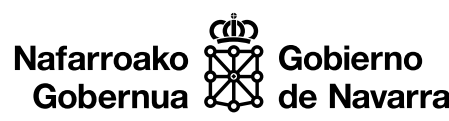

0000 


\section{Sumario / Aurkibidea}

\section{Fontes Linguae Vasconum. Studia et Documenta}

Año XLVIII. urtea - N. o 122. zk. - 2016

Uztaila - abendua / Julio - diciembre

Erroibarko aldaeraren inguruan

(3 - Hego Erroibarko azpialdaera. Bigarren erdia)

Koldo Artola

Etxarrierako hitano-alokutiboa

Jose Luis Erdozia

An introduction to Basque aspiration: the contribution of onomastics

Patxi Salaberri Zaratiegi, Iker Salaberri Izko

Urretabizkaiaren eta Sarrionandiaren itzulpen-habitusak

Miren Ibarluzea

Julian Gaiarreren euskal gutuna: edizioa eta azterketa

Koldo Ulibarri

Zozo zuriaren xerka: euskararen optatiboaren historia

Manuel Padilla-Moyano

Euskarazko erlatiboen diakroniaz: testu zaharren azterketa

Dorota Krajewska 


\title{
An introduction to Basque aspiration: the contribution of onomastics
}

\author{
Patxi SAlaberri Zaratiegi ${ }^{1}$ \\ UPNA/NUP and Euskaltzaindia \\ Iker SALABERRI IzKo \\ $\mathrm{UPV} / \mathrm{EHU}$
}

\section{INTRODUCTION}

This paper is the response to a need of ours that arises when working in the field of toponymy, in order to provide a satisfactory etymological explanation to data at hand. The study of Alavese place names (see Salaberri Zaratiegi, 2015) presents, to a greater extent than the study of toponymy from other regions of peninsular Vasconia, a slight «inconvenience»: particularly (though not only) the medieval variants frequently display one, two or, in rare cases, up to three $h$ s which the investigator is compelled to account for in case he wants to come to fruition in his task to etymologically elucidate toponyms, even when this does not fit together with what he has in mind. This is the case, for example, of the variant containing an initial $h$ of the toponym Araia, which is based, in our opinion, on the person name Arai (in the genitive) that is attested in Ilarduia and Kontrasta (Elorza, 1967: 136; Gorrotxategi, 1995: 218) and probably present, as well, in the basis of Araiko, the name of another village (see Salaberri Zaratiegi, 2015: 82-84).

It is therefore this necessity, behar eta premia gorria, as one would say in Basque, which brings the onomastician to delve into territories which are, if not completely uncharted and unknown to him, then at least not at all familiar and full of traps and

1 We would like to express special thanks to the Colombian phonologist Camilo Enrique Díaz Romero for the relevant remarks made about this paper. We are also grateful to the anonymous reviewers of this article for bringing so many points with such accuracy to our attention. 
dangers, such as phonology, typology and the study of protolanguages, not to mention dialectology to which, by necessity, the onomastician stands closer, even if it is just because he feels compelled to include, within the task of standardizing toponyms, the features that are typical of the variety spoken in the area he is examining.

We have not sought to be exhaustive in any field. Clearly there are more authors and works worthy of being quoted among the ones mentioned in the discussion of the various topics hereby analyzed. Only a small amount of the dialectology data we use is home-grown: in general, we draw on the excellent compilation and interpretation work currently being carried out by Iñaki Camino in northern Vasconia and, likewise, on the sheer amount of work entailed in Euskararen Herri Hizkeren Atlasa by Euskaltzaindia (Academy of the Basque Language). With respect to the data concerning typology and Proto-Basque, we mostly rely upon the articles by professors Iván Igartua and Joseba Andoni Lakarra. Data concerning ancient onomastics result from the manifold contributions by Koldo Mitxelena and especially Joakin Gorrotxategi.

The sources for later onomastics data are made up by diverse document compilations which have, for the most part, been published in recent years. These data are gathered, at least partially and in what concerns Álava, in the above-mentioned work (Salaberri Zaratiegi, 2015). The interested reader can make use of it whenever he wishes to find out the data contained in a specific Alavese toponym. We should nonetheless admit that there is still a lot to be done in the field of (major and minor) Alavese toponymy as well as in other regions of Vasconia. In this sense the publishing of medieval records being carried out by Eusko Ikaskuntza in the compilation Fuentes documentales medievales del País Vasco (Medieval documentary sources from the Basque Country) as well as the gathering and analysis of minor toponymy published by Euskaltzaindia in its compilation Onomasticon Vasconiae are two essential tools the investigator must make use of.

With regard to the structure of this paper, first of all, we exhibit the positions within the word in which aspiration can appear in Basque, following which we account for the restrictions aspiration is subject to. In the third place we summarize the views held by those authors who have denied the etymological character of Basque aspiration. Subsequently, and once its etymological character has been established in most cases, we point out this sound's historical sources. In the following point we briefly discuss the loss of aspiration and, to conclude, we analyze the contribution to the field that the study of western Basque toponymy can make, providing, however, data from other areas of southern Vasconia as well.

\section{POSITION OF ASPIRATION WITHIN THE WORD}

Aspiration has been historically pronounced -and it still is- in the northern dialects spoken in the so-called French Basque Country. The positions in which aspiration may appear are the following (Mitxelena, 1977: 203 and further): 
a) In the first syllable: háitz, haitz "oak", háize "wind", hámar "ten", háundi "big", hégo "south wind", heskwára "Basque", hétsi "to close", híru "three", hobén "blame", hódei "thundercloud", huntzósto "ivy", hurtátu "to water".

b) In the second syllable, in intervocalic position: ahálge "shame", ahári "ram", ábo "mouth", behár "need", bihíkatu "to shell", lahár "bramble", ihiondo "rush", lehértü "avalanche", "landslide", méhe "thin", mihise "bedsheet", nábi "wish", uhár "cloudburst", xehátü "to damage", "to devastate". Also in Ancient Basque (we follow the periodization made by Lakarra, 1997a: 516) aspiration could stand in intervocalic position, though not only in the second syllable: Bihoscinnis, Ulohoxis (Aquitania, Mitxelena, 1954: 418-420), Vmmesahar (Lerga, Mitxelena, 1961). In the Middle Ages we encounter the personal name Ahardia (Villabáscones, BU, 956; Martínez, 1998: 119), based on the noun ahardia "(the) sow" (cfr. Garindo Aquetza "Garindo the boar, the male pig”, N, ca. 1173, Jimeno, 1968: 241).

c) Between a diphthong and a vowel: ainhén "vine", aunháldu "to dine", einhéra "mill", oỉhán "forest", or between a vowel and a diphthong: ihaurgéi "straw bedding", iháuntiri "carnival", mahái "table", ohóin "thief".

d) Before a vowel following a sonorant, which constitutes heterosyllabic clusters: al.hágü "pasture(-land)", él.he "word", el.hestátü "to chat", ér.hi "finger", il.hár "bean", il.hárre or il.harréski "heather", il.hún "night", lán.ho "fog", "cloud", "morning haze", sen.hár "husband".

This we already find in the Roman-period inscriptions in Navarre: Narbunges, Abisvnhar (Lerga, Mitxelena, 1961; Gorrotxategi, 1984b: 263), as well as in the Aquitanian inscriptions from the same period: Berhaxis, Erhexoni (Gorrotxategi, 1984a: 163, 205) and even in some from Aragón (Dusanharis, Serhuhoris, Gorrotxategi, 1995: 227). According to Hurch (1987: 44-45), the fact that we are dealing in this case with heterosyllabic clusters, as opposed to e.phél "lukewarm", for example, is due to «the aspiration of stops [being] more natural than the aspiration of sonorants». Currently one also finds $\tilde{n} . h$ in a ñ.hárba (Z; Camino, 2015b: 52) and rr.h in ürrhitz "hazelnut tree" (Arrueta, NB, EHHA).

e) In some varieties aspirated voiceless stops are found ( $p h, t h, k b)$ : ápho "toad", athérbe, atherbé "rain shelter", béthi "always", ékhi "sun”, gáthü "cat", ikhúsi "see", intha "marsh", "swamp", khárrüñ "black frost", khórbe "manger", lépho "neck", "hill”, óthe "gorse" (and óte, which has the same meaning),

2 According to Camino (2015b: 47), in Amikuze (NB) khorbe means "wooden manger attached to a wall" and "trough" in Landibarre (Oztibarre, NB). This author points out in a footnote that outside of Amikuze this word is only used in Landibar, but that is not completely true: in Luzaide (N; see Kamino \& Salaberri, 2007: 83), for example, górbe means "place where cows are fed fodder". 


\begin{abstract}
pházko "Easter", phéntze "fenced meadow", thállu "scythe", ukhán "to have", urthárril "January", xaphár "quickset hedge", zakhúr "dog”. In this case, when the first two syllables begin with a stop that can be aspirated ( $p$, $t, k$ ), the initial syllable has priority (Mitxelena, 1951: 546, 1977: 212): phika "magpie", khórte "court (of a monarch)", théka "pod", and so on. A characteristic of Proto-Basque as well as a typological feature has been observed here, according to which languages with falling accent (and consequently SOV order) tend to pronounce the first stop more prominently (Igartua, 2001: 195, 197; 2002: 377).
\end{abstract}

From the point of view of Natural Phonology the coexistence, in some varieties of Basque, of an aspirate phoneme and aspirated voiceless stops should be due to their being considered to be the same phonological phenomenon. This point of view has advantages at the time of explaining the emergence or loss of aspirated phonemes, such as aspirated voiceless stops, since it predicts that they should appear and disappear simultaneously (Hurch, 1988: 42-44) ${ }^{3}$, as occurs in the Basque varieties that have lost aspiration.

\title{
2. CONSTRAINTS
}

Aspiration is never found in a syllable that begins with: a) a voiced stop, b) fricative, c) affricate, d) nasal, e) voiceless stop preceded by a sibilant, f) in words in which there has or previously had been a palatal sound: ttipi, güti... (Mitxelena, 1951: 544; this is «typologically fairly widespread», according to Hurch, 1987: 47, but we find Gastea Guthi in Bañares, La Rioja, in 1183, Ag. Ubieto, 1978: 54, whose second member might be palatalized. Cfr. current gúti / gútti / gútxi; "gútthi is impossible nowadays $\left.{ }^{4}\right), g$ ) in the root of conjugated verb forms, since "the phonetic constraints they are subject to are not the same ones that constrain names» (Mitxelena, 1951: 541 , footnote 6$)^{5}$.

In addition there is a rule that restrains aspiration to the first two syllables of a word. According to Igartua (2001: 195-196, 2002: 376), this fact would correspond to the gradation of pronunciation energy, which would decrease over time. Notwithstanding, in Aquitanian aspiration could also appear after the second syllable: Artahe, Artehe, Dvnohoxsis (Gorrotxategi, 1984a: 199, 308 and 1984b: 264), and the same is the case

3 Hurch claims thus (ibid.: 43): «Die Richtigkeit der ersten in diesem Abschnitt gemachten Behauptung, daß/h/ und die Aspiration von Konsonanten als ein und dasselbe Phänomen zu betrachten sind, liegt in der Auffassung des einheitlichen Prozesses der Eliminierung von Aspiration, der in folgenden zu behandeln sein wird, begründet".

4 Notwithstanding Camino (2015b: 55) mentions otthé "cricket", from Pagola (Z).

5 «Las condiciones fonéticas a que [las formas personales del verbo] están sometidas no son las mismas que las de los nombres». 
in Abisunhar, from the Lerga inscription (Mitxelena, 1961). A medieval example is $L a$ rrandoren bi sarohe "two enclosed meadows ${ }^{6}$ in Larrandore" $(1284)^{7}$.

\section{REGARDING THE ETYMOLOGICAL CHARACTER OF BASQUE ASPIRATION}

In the historiography of Basque aspiration has been regarded as essentially non-etymological until Mitxelena (1950 and onwards), except for the precedent of Meyer-Lübke (1924). The latter author draws a parallel between the change of intervocalic $n>b$ in Bearnese and in Basque, thus suggesting that Basque aspiration may be etymological. Meyer-Lübke (1924: 210-211) is also the first one, based on data from synchronic dialects, to point out that nasalization of the vowels preceding and following $n$ is a necessary step in the process, as well as to observe that reflexes of a lost $n$ can be found in the form of nasalized vowels. Regarding those authors that do not believe Basque aspiration to be etymological, Schuchardt (1906: 22) asserts that one cannot speak of a change $n>b$ and considers that in unstrained (that is, natural) speech there is no full pause between two vowels, which is to say that there are no hiatuses, and that the insertion of $b$ is due to the wish to avoid their existence. This author, in a later work (1908: 6) and without challenging the fact that $b$ is present in the Aquitanian data, considers that in many cases aspiration was subsequently adopted, which was facilitated by the introduction of borrowings with said sound. Gavel (1920: 265-266), on the other hand, wonders whether words that originally had $-n$-, such as katea (< catena), lost the nasal after their introduction into the Basque language or before, since «it is indeed well-known that in some Romance dialects, such as in Bearnese or in some varieties of Gascon, the primitive loss of intervocalic $n$ is common ${ }^{8}$.

Another of the linguists who denied the etymological value of Basque aspiration is Trask (1997: 157-158). This author acknowledges that aspiration existed and was written with an $b$ in the Aquitanian inscriptions «in approximately the same positions in which it occurs today in those dialects of Basque which retain the aspiration", but he considers that $h$ does not follow a previous sound, and that aspirated stops are originally no different from the unaspirated ones.

Trask considers that aspiration arose as a suprasegmental feature related to word accent position. He also considers that said suprasegmental origin is responsible for the constraints governing the distribution of aspiration. He only acknowledges the

6 The word sarohe (saroi at present) refers to an area which includes, on the one hand, a fenced field or meadow for cattle -usually sheep- to graze and, on the other hand, a shelter (borda) for the cattle to sleep and be protected against bad weather as well as a hut for the shepherd (etxola).

7 This could refer to present-day Larrondone, in Luzaide (N), which is a place found near mount Adartza, by the Banka (BN) border, but it is more likely to refer to Larrandoine, a mountain in Arnegi (BN), not far from Orbaizeta (Aezkoa, N).

8 «On sait en effet que dans quelques dialectes romans, tels que le béarnais et certaines variétés du gascon, la chute des $n$ intervocaliques primitive est normale». 
etymological character of $h$ in harri "stone", "which may be related to the substrate element "karr- "rock, crag" attested in Romance and Celtic" and in the demonstratives hau(r) "this (one)", hori "that (one)", hura "that (one)", which are kaur, kori, kura or gau, gori, gura in the Pyrenean dialects. Trask concludes claiming that "no one is quite sure what to make of these cases» (ibid.: 64).

Uhlenbeck (1947: 551) considers that the $b$-found in demonstrative pronouns in the «Basque French patois» is the last remnant of a previous guttural sound, of a $k$-, and that the primitive form of arri or harri must have had said sound, that is to say, it must have been "karri. According to Bähr (1948: 172) Basque aspiration is etymological and, in a specific period, common to all dialects ${ }^{9}$. Regarding its origin, this author holds that «here it should be borne in mind that $h$ could have developed out of an older $c h, k b$ or $k$, as for example sporadic cases of kau, gau next to hau, au "this (one)" or very old compounds like hazkazal "nail", from hatz "finger" and hazal "skin" lead us to believe»" In Mitxelena's (1957-58: 232, footnote 1) opinion, the $h$ found in demonstratives «seems to be the continuation of a dorsal plosive preserved in certain Navarrese varieties ${ }^{11}$.

Nonetheless, and regarding the etymology of harri, it is not at all clear that it comes from a form with * $k$ - (see Lakarra, 2009: 218-219; 2010b: 206, footnote 44b and Igartua, 2011: 911) $)^{12}$ and, concerning the initial velar found in demonstratives, it could either be a late addition similar to the one so many suffixes have taken (Lakarra, 2011: 185 and 2015a: 432, footnote 37) or originate in aspiration, as a kind of fortition (Igartua, 2011: 910, footnote 19 and ibid.: 911). In any event, most linguists have considered Basque intervocalic aspiration to be etymological and to come in many cases from an earlier nasal, both in Latin-Romance borrowings and in inherited words.

Mitxelena (1950: 448) mentions ahate "duck" and ohore "honor", which in Souletin are ãhãte and $\tilde{u} h \tilde{u}(r) e$, in High Navarrese aate and oore, the second of which is orre in Roncalese. These are doubtless examples of the evolution $-n->-b$-. The aforementioned author does not feel «any need to turn to epenthetic and antihiatic consonants, as is done somewhat frequently» ${ }^{13}$, and believes that we are dealing with a phenomenon

9 «Diese Tatsache, dass vor nicht langer Zeit sämtliche Dialekte ein $b$ besassen (sic), ist so offenkundig, dass sie keinen Zweifel gestattet».

10 «Dabei ist jedoch zu beachten, dass ein $h$ sich aus älterem $c h, k b$ oder $k$ entwickelt haben kann, wie z. B. sporadisches kau, gau neben hau, au "dieser" und sehr alte Zusammensetzungen wie hazkazal "Nagel" aus hatz "Finger" und hazal "Schale" vermuten lassen".

11 « $h$ semble être le continuateur d'une occlusive dorsale conservée dans certains parlers navarrais».

12 In personal communication Lakarra tells us that there are four reasons not to acknowledge the etymology *kar for Basque harri: 1) it would be one of the few possible etymologies; 2 ) out of an older " $k$-, $g$ - would be expected in Basque; 3 ) it would be unusual for a borrowing to take the suffix $-i$; and 4) harri belongs to the family of hartz "bear". No loanword seems to exist that has taken the suffix - $t z$, also found in beltz "black" and hortz "tooth". The interested reader should look at the 2009 article by said professor and scholar, footnote 33 .

13 «No veo ninguna necesidad de recurrir a consonantes epentéticas y antihiáticas como suele hacerse con alguna frecuencia». 
similar to the one occurring in Gascon, in which «a shift from apical $n$ to dorsal $n$, together with nasalization of the previous vowel and its subsequent change into an aspirate (to a voiced laryngeal fricative) $\gg^{14}$ has taken place. That aspiration existed in Ancient Basque is beyond any doubt in view of the names in the inscriptions: Vmmesahar (Lerga, N), Larrahe, Larrahi, Larahe (N, Gorrotxategi, 1995: 227 and 2015: 300), Helasse (A, Gorrotxategi, 1984a: 330 and 1984b; see Velaza, 1992), not to mention the Aquitanian material.

\section{SOURCES OF ASPIRATION IN BASQUE}

4.1. A previous Proto-Basque $h$ (see Mitxelena, 1977: 208): bihotz "heart", hartz "bear" (cfr. Bihoxus, Harsi in Aquitania, in the first centuries of our era, Mitxelena, 1954: 434, 436; Gorrotxategi, 2002: 83 and 2015: 298). In Proto-Basque (Lakarra, 1997b: 588 and Igartua, 2002: 385 and 2011: 907) the roots that did not begin with a consonant had to carry initial aspiration ( har "take", hel "arrive", hil "die, kill"), and for that reason there were no roots that began with a vowel. There was a CVR structure, which could also be CVRS (bortz "five"), where S would be a suffix. Therefore, during this first stage aspiration was bound to the root and did not always depend on the accent. According to Igartua this means that ákher "male goat", ártho "corn" (previously "millet") or álhor "plowing field" might originally have been "ha $(n) k h e ́ R$, "harthó and "halhóR, which, by means of a deaspirating process, turned into their current forms, already based on the expansion of disyllabic roots.

4.2. Latin $f$-, with or without Romance mediation: forma > horma "wall". In these cases one might better think of Gascon etymons carrying $b$-, since Latin $f$ - usually yields $b$ - in Basque, and Romance $f$ - results in $f$ - (Lakarra, 2015b: 362-364). Igartua (2011: 902) mentions typological parallels in many languages and quotes Wallace $\&$ Joseph (1991), for whom $f>b$ is a natural change. We can point out here, as an illustration of the tight relationship between /f/ and /h/, the fact that in the present-day Luzaide $(\mathrm{N})$ variety ólf]e "bed" is the pronunciation of what is elsewhere pronounced ólb]e (see Kamino \& Salaberri, 2007: 146).

4.3. A previous intervocalic $-n$ - at the onset of the second syllable: "bini $>$ "bibi > mibi "tongue", linu > lino > liho "linen", with three intermediate stages involving (a) lenition of the nasal into a voiced, nasalized aspirate still preserved in Souletin Basque, (b) nasalization of the surrounding vowels preserved as phonemic nasal vowels in older Biscayan and the extinct Roncalese, and (c) altogether loss of nasality of the aspirate and the surrounding vowels in dialects like Labourdin and Low Navarrese $(-n->(-\tilde{h}-)>$ $(-\tilde{V} \tilde{h} \tilde{V}-)>V h V>-h-)($ Hualde, 2015: 138).

14 «El paso de $n$ apical a $n$ dorsal con nasalización de la vocal anterior y su conversión ulterior en una aspiración (una fricativa laringal sonora)». 
While historical Basque made an opposition between a fortis $(N)$ and a lenis $(n)$ nasal, this change only affects the lenis nasal, after which lenition of the fortis takes place $\left({ }^{*}-n->(-\tilde{h}-)>-b-,{ }^{*} N>n\right)$ (Igartua, 2015: 646). The reason why the fortis was not replaced as well by aspiration is due to the replacement of $-n$ - by $-h$ - only occurring in phonetically relaxed environments (see below). In addition ${ }^{*} N$ may have been pronounced heterosyllabically. Accent may also have played a role in this assymetry; for more details see Igartua (2015).

Regarding the chronology of this change, because it affects all modern Basque varieties but does so differently, the first step $\left({ }^{*}-n->-\tilde{h}-\right)$ is assumed to have begun in a period antedating the splitting up of Ancient Unified Basque into dialects, possibly sometime in the early Middle Ages. The rest of stages might have occurred after the diversification of Ancient Unified Basque (Hualde, 2015: 138).

In spite of Trask's objections (see above), and in case it was not clear enough after the examples provided by Mitxelena, Igartua (2008a, 2008b, 2015) now draws on typology, on the so-called rhinoglottophilia in order to explain this change, which «entails a curious diachronic permeability between nasalization and laryngealization» (2008a: $177)^{15}$ and speaks, therefore, in favor of said change. This typologically observable connection between glottality and nasality is motivated by both articulatory and perceptual effects (Igartua, 2015: 635), even though the latter are probably more important than the former (ibid.: 654).

In articulatory terms, aspiration, like nasality, favors a longer period of glottal opening because the air flow is greater than in the case of non-nasal and non-aspirated sounds (ibid.: 645). In perceptual terms, the articulation of aspirates requires, in addition to opening the oral cavity, also opening the subglottal cavity. The articulation of nasals requires opening the oral and the nasal cavity, thus creating acoustic effects similar to aspiration. These articulatory and perceptual features of aspirates and nasals are frequently extended to surrounding vowels, leading to a confusion between and eventual reanalysis of pre- or postaspirated vowels as nasal and viceversa (ibid.: 645-646).

According to the same author (Igartua, 2008a: 171), «from a typological perspective, the diachronic correspondence $-n->-b$ - is perhaps the most marked development in the phonological history of the Basque language». Furthermore, this linguist considers (ibid.: 187) that, in order for $-n->-b$ - to have taken place in Basque, the phoneme $/ \mathrm{h} /$ must have been part of the language's sound inventory. This argument supports the antiquity of aspiration, which was already pointed out by Mitxelena (1950: 454).

15 «La rhinoglottophilia entraña una curiosa permeabilidad diacrónica entre la nasalización y la laringalización». This "permeability between nasalization and laryngealization» is, moreover and contrary to most cases of sound change, symmetrical. This means not only that nasally articulated sounds can shift to being articulated glottally, as is the case in historical Basque of $-n->-b-$, but also that glottal sounds can change to nasal ones (even though this latter change is more seldom than the former), as the author (Igartua, 2015: 637) points out. 
4.4. Former voiceless or fortis stops in initial position ${ }^{16}$. Out of the four sources this one is the most difficult to prove. Although "karr has already been mentioned as an etymon for Basque harri "stone", where the final palatal vowel could be a suffix, there is little more than that (see above). To Mitxelena (1950: 445-446) it was not completely clear that $k$-changed to $b$-, «because it is hard to understand why $k$-has been preserved or has become voiced in so many cases and has been lost, through an intermediate $h$-, in others $»^{17}$. In a later article (1954: 451) he writes that in the current language "there are no apical stops, whether voiced or voiceless, in that position (that is to say, $t-, d-$ ) in nominal forms ${ }^{18}$, except in loanwords and expressive words, but he considers that this is a recent phenomenon and that "a means [of explanation], among others (assibilation, etc.), is clearly for some Aquitanian initial aspirates to be the reflex of a lost apical stop ${ }^{19}$ (ibid.). This is to say that a shift $t->b$ - may already have taken place in Aquitanian, in some names at least. In his masterpiece (1977: 219-220) Mitxelena finds it difficult to specify which of the lost initial stops left aspiration as a trace.

Gorrotxategi (1984b: 264-265) mentions Talsconis / Halsconis (see Mitxelena, 1954: 451), Baiso-thar [, Hon-tharris, Halsco-tharris, where th might represent an aspirate stop. It should be kept in mind that currently the demonym is both -tar (bizkaitar "Biscayan") and -ar (donostiar "native to Donostia or San Sebastián"). According to Mitxelena (1954: 447), the original one would be -tar, out of which came -ar due to stress restrictions.

4.5. In historical Basque an aspirate has arisen between hiatus vowels, as is illustrated by the personal name Johane "John", Johañe "little John" or the verbal form doha "(he/she/it) goes", which is used by Etxepare next to doa (Lafon, 1948: 58). These are derived forms of the verb johan "to go", which is currently used in Amikuze (NB) (Camino, 2015b: 37). Nevertheless, and according to Lakarra (2012: 668), the aspiration is etymological in the last case, since in his opinion johan comes from *edanon (> *edahon $>$ *edohan $>$ johan).

4.6. Aspiration has sometimes developed after a sonorant $(n, \tilde{n}, l, l l, r$ and $r r)$ : bílho "hair" (Mitxelena, 1951: 548), gelhari (< cellarius, in this author's view), manha "to command" (by analogy, Mitxelena, 1977: 223), sorbo "pasture, plowing field", all clear borrowings. Notwithstanding, according to the same linguist (1957-58: 225) «by a

16 This might be the source of aspiration with the highest number of typological parallels. In addition to the sources gathered by Igartua (2008a: 173), we may mention the so-called Grimm's Law or Germanic Consonant Shift, according to which, among other changes, Proto-Indo-European / $/$ changes to Proto-Germanic /x/ and eventually yields / $\mathrm{h} /$ in initial position in the Old Germanic languages (Grimm, 2009 [1848]: 399-401).

17 «Porque no se ve muy bien por qué $k$ - se ha conservado o sonorizado en tantas ocasiones y se ha perdido, pasando por $h$-, en otras».

18 «En vascuence se puede afirmar rotundamente que no hay oclusiva apical, sorda o sonora, en esa posición en formas nominales».

19 «Y una posibilidad entre otras (asibilación, etc.) es, claro está, que algunas aspiraciones iniciales aquitanas sean el reflejo de una oclusiva apical desaparecida». 
specific period, aspiration was only preserved before the stressed vowel, which in this sense would usually be that of the second syllable of the word $»^{20}$, whilst nowadays one gets ákher "male goat", álhor "plowing field". These should be due to a later leveling, by which a syllable count is made beginning from the end of the word (ibid.: 233), but consider báke "peace", mérke "cheap", zéta "silk", where the position of the original stress is preserved, all of which occurs in Souletin or Zuberoan Basque.

The differences found in the Aquitanian data might be due to stress usually being in second position: Hontharris, but Harontarris, Halscotarris, without aspiration in the third syllable. However, the fact that $<\mathrm{h}>$ does not appear in certain inscriptions does not completely ensure that aspiration did not exist in the names found in them. There is, nonetheless, another possibility according to Igartua (2002: 383), since in such names as Baisothar [ the $h$ goes in the third syllable: the aspiration contained in the element that turned into a suffix may have spread to other positions, and it could be thought that, by the time, stress was not fully tied to the second syllable anymore. This fact may have brought the end of the system according to which stress is fixed on the second syllable.

4.7. At the beginning of the second member in compounds, after a diphthong, when the first member is monosyllabic: de(in)hádar "shout", gaunérdi "midnight" (< gau "night" + erdi "half").

4.8. The tap or flap at the end of the first member of the compound, at least in the case of the nouns ur "water" and zur "wood" (ura and zura respectively, when adding the article): Uharte "area between two waters" or zuha(i)tz "tree" (toponyms Zuhatzu, Zuhatzola, etc.). The same thing occurs with the trill in the term lur "earth" (lurra with the article) on occasion: luharbil "lump", lübidorrez "over dry land", "by land" (as opposed to "by sea"). In case this should be considered a direct phonetic change, it would have tenuous typological support (Igartua, 2006: 521; 2011: 896).

This author $(2006$ : 527-528; 2011: 908) prefers to think that, in the case of uhalde, uharte or uholde, the $-h$ - was already present at the beginning of the second member, which is why one would be dealing with a dissimilation *hur-halde $>$ "urhalde $>$ uhalde. Lakarra (2015b: 357) considers that there are few morphemes ending in $-r$ which display an alternation $-r /-h$ and concludes that «by the historical period the rule only applied to a few words, that is to say, it was lexicalized $»^{21}$. He believes, on the other hand and as opposed to what Igartua considers, that the initial $h$ s at the beginnings of second members are unnecessary to explain the substitution $-r>-b$ and that it is easier to assume $-r$ $>-h$ «on the basis of the well-known rule $* h . . . h>\varnothing \ldots . . h$, which lacks exceptions ${ }^{22}$ (ibid.: 358). This is to say, $" b V r>* b V h>V h(>\ldots)$, for example hur- $>* h u b->u b->i(b)-$.

20 «À une certain époque, l'aspiration ne s'est conservée ou produite que devant la voyelle accentuée qui, de ce fait, serait normalement celle de la deuxième syllabe du mot".

21 «Badirudi, aldiz, erregela hitz gutxi batzuetara mugatua zela garai historikoetarako, hots, lexikalizatua».

$22 « " h \ldots h \ldots>\varnothing \ldots h$ erregela ezagun eta salbuespen gabearen bitartez». 
4.9. Another modern source of aspiration (from the 18th century onwards at least) is a tap or flap ([r]), found in terms different to ur or zur outside of composition. For example, in Luzaide (N) one finds ahán (< aran) "plum", kubútze (< gurutze) "cross", etc. It has been thought that, for these forms to arise, there must have been an intermediate phase -rh-, with creation of the aspirate after the sonorant. This could be the case for Souletin eri "finger" > erhi > ébi or soro > sorho > sóbo, and perhaps, as considered by Camino (2015a: 22), for the Basque spoken in Oztibarre (NB) and elsewhere. As far as we know, however, attestations of $r h$ in the Luzaide variety are completely lacking, where, notwithstanding, terms such as ahán and kubútze are known. Thus, we get éri "finger" and sóro "second-growth hay" (not sorbo), next to a variant sóbo (Kamino \& Salaberri, in preparation).

4.10. Mitxelena (1977: 213) quotes tahárna "inn", where aspiration comes from another voiced fricative, taberna, even though here it is possible to believe that the variant that gave rise to the form with $b$ contained a voiceless labiodental fricative (taferna). Such an evolution seems to have taken place in Nafarruri (LR, 1070, García Andreva, 2010: 402; 1199, Ag. Ubieto, 1978: 69), Naharruri (1104, García Andreva, 2010: 830; 1210, Ag. Ubieto, 1978: 82), Navarruri (ca. 1156, ibid.: 31, 33), currently Casalarreina. This is a composite toponym of the ethnic name Nabar, which comes from the demonym "nabar, nafar "Navarrese". Here the original sound is $-b$-, since the labiodental fricative did not exist in the phonetic inventory of Ancient Basque (Mitxelena, 1977: 374).

Currently, in the Luzaide variety aspiration may indeed come from a word carrying $[\beta]$ : ahántxu < abantxu "almost", gohórnu < gobernu "government", and so on, or from one carrying $[\gamma]$ : gohótik < gogotik "willing (to)", gohór < gogor "hard". Camino (2015a: 22) explains that in Donibane and Lekunberri (Garazi, NB) ibili is used, from ibili "to walk", and in Uharte (same region) zahaldu "to (become) open", "to spread", whereas in many districts in Oztibarre gibil "rear", "liver" is a normal form. In EHHA there is iháitja "to go up" in Arrueta (NB), from a previous igaitea, or perhaps from a former iraitea. Cfr. irán "to go up", "to climb up" in Luzaide (N).

4.11. Occasionally we are dealing with a parasitic $h$-, in hiraka "darnel" (Latin ebri$a c a)$, but in some cases a crossbreed can take place with other synonyms or quasi-synonyms due to their etymology: harroka, which results from crossbreed between arroka "rock" and harri "stone", "crag", "rock"; hezkabia "ringworm" (Latin scabies) would be the result of crossbreed with hatz "mange" (Mitxelena, 1977: 206). This author claims (1954: 434) that Basque initial aspiration is too labile to draw any conclusions from comparison, that it «spread in a completely unexpected manner $»^{23}$ and that «therefore we are not dealing simply [...] with preservation or loss, but on the contrary, very often we are dealing with the birth of aspiration» ${ }^{24}$ (1957-58: 224).

23 «...l'aspiration a proliféré de façon tout à fait inattendue».

24 «Il ne s'agit donc simplement [...] de conservation ou de perte, mais au contraire, très souvent, de la naissance de l'áspiration». 
Mitxelena (1977: 209) believed that $h$ comes up in borrowings without any reason, in harea "sand", for example. Notwithstanding, in a previous article (1950: 458), after putting forth that he had to give up his explanation of Souletin hariña $<$ "areha < arena "because in that position aspiration, if it ever existed, must have been lost at a very early period $»^{25}$, he mentions his assumption in a case of metathesis, for which he draws on Roncalese ãre "sand" and gãzta "cheese", this last one from "gaztana, in Souletin gazná. This is to say, it seems that, here at least, he does not completely rule out that the $h$ in harea (or hariña) be the result of aspiration of the nasal of the third syllable in the etymon, since vowel nasalization caused by the shift $-n->-b-($ that is to say, $-V n V>-\tilde{V} n \tilde{V}>-\tilde{V} \tilde{b} \tilde{V})$ has moved to the first syllable in Roncalese.

Lakarra (2009: 221 and further) believes that in cases like harea the initial sound is etymological, and on the whole the result of movement of a previous aspirate onto initial position whenever this position was free, which is to say whenever the word began with a vowel (harea < *areha < arena). He refuses Igartua's (2006, 2008a: 173) explanation, which in a similar but not identical manner to Trask draws on prosody to explain some of the non-etymological $h$ s that Mitxelena had mentioned. Lakarra (ibid.: 223) admits, nevertheless, that on occasion there is indeed an analogical $b$ in the forms that had undergone $h 3>b 1$ or $h 2>b 1$.

Igartua (2001: 191, footnote 13; 2002: 371-372, 2011: 906-907), by contrast, considers that the aspiration of harea and lehoi $(<$ leone) is related to the position that the accent had in those terms in Latin, and he believes that it is problematic for harea to come from "areha, since a form "arhea, similar to erhi "finger", for example, would be perfectly possible. Regarding lehoi, he considers that the development of aspiration is tied to the accent (leóne > lehói). Igartua (2008a: 174; 2011: 906-907) writes that said change $(h 3>b 1, h 2>b 1, h 3>h 2$ ), if it really occurred, might have a prosodic character; aspiration would be a feature to a great extent subsidiary of accent. He believes (2011: 912-913) that if the aspiration of the third syllable was endangered, its preservation may have been considered a priority with respect to its syllable placement, so as to distinguish two different kinds of words.

4.12. Mitxelena (1957-58: 224) regards the form onherran "to bless" as tied to accent position. He writes (1951: 549) that, in compounds such as the mentioned one, where the second member is disyllabic «a retreat of the accent of the last element ${ }^{26}$ must have taken place, that is to say, and if we have understood correctly, a change onerrán > onérran > onhérran must have taken place. However, in Lakarra's (2015b: 365) opinion the - $h$-found in compounds like onherran (hon "good" + erran "say"), onheritzi, onhetsi "to love, want" (hon "good" + eritzi, etsi "to consider, judge") is the result of

25 «...porque en esa posición, la aspiración, si existió alguna vez, debió perderse en fecha muy temprana».

26 «...una retrotracción del acento del último elemento». 
the shift $h 1>h 2$, that is, of metathesis $h V R->V R h-$, which would be fairly modern, later than $* h 3>h 1$. This metathetic process would be supported by the position of the accent in the second syllable (ibid.: 369 , footnote 54 ).

4.13. It seems as though in the Middle Ages, in some occasions, $b$ was only used to divide syllables, and the same thing happened, according to Mitxelena (1954: 424), in Aquitania: Artahe, Artehe, Herauscorritsehe, etc.

4.14. In some varieties we find aspirated stops $(p h, t h, k h)$ which to all appearances are, in most cases, nothing but phonetic variants of the plain stops, whose aspiration is due to their position with respect to accent (Mitxelena, 1957-58: 224-226). This is to say that they do not have a distinctive or phonological value (Lafon, 1948: 60, Mitxelena, 1950: 446 and 1977: 208, Hurch, 1987: 38, Igartua, 2002: 368-369 and 372-373). It is for this reason that we have néke "fatigue" next to nekhátu "tired", or jókü "game" next to jokhátü "played". There are, nonetheless, some attestations such as okher "crooked, bent" as opposed to oker "burp", but the productiveness of the opposition plain vs. aspirated voiceless stop is very low (Mitxelena, 1977: 208 and Igartua, 2001: 187).

4.15. It is interesting to note that all of the above-mentioned sources of aspiration concerning the lenition of an oral or nasal sound to $[\mathrm{h}]$ or $[\mathrm{h}]$, regardless of voicing, the phonological environment and the position in the syllable where such a change occurs, can be viewed as belonging to the same category of change. This category of lenition processes is called "debuccalization" and it involves a case whereby "some consonant no longer has any obstruction or gesture in the oral tract, and the sound that results is a laryngeal consonant $([\mathrm{h}]$, [h] or [?])»(O'Brien, 2010: 2). Debuccalization can be motivated by perception, dissimilation from neighboring sounds or the need to avoid neutralization. The reason why the original sound does not simply disappear is that «some aspect of the underlying sound must remain, and debuccalization is one way to balance articulatory ease and faithfulness [i.e. to the original sound]» (O'Brien, 2010: 24). Thus the change in different stages of historical Basque of $[\mathrm{f}],[\mathrm{n}],[\mathrm{k}],[\mathrm{t}],[\mathrm{r}],[\mathrm{r}],[\beta],[\gamma]$ to $[\mathrm{h}],[\mathrm{h}]$ may be regarded as one and the same process. The idea that these lenitions should be regarded as a unitary phenomenon of debuccalization occurring in Basque is first pointed out by Igartua (2015: 652-653). Therefore, and because the secondary emergence of aspiration in Basque can be seen as one process, it is unsurprising that its loss in some dialects can also be considered as unitary, in the lines of Hurch (1988: 42-44). For more discussion on debuccalization see O'Brien (2010).

\section{LOSS OF ASPIRATION}

As has been shown, the modern dialects do not allow for two hs in the same word. For this reason, whenever two aspirates join together in composition, the first one is usually elided by means of regressive assimilation, which is motivated by the second member bearing accent in compounds (Lakarra, 2010a: 573). 
Igartua (2001: 198, footnote 36; 2002: 378, footnote 35) believes that the dissimilation or deaspiration which affects the first syllable is not, strictly speaking, a case of dissimilation, since it occurs because it is the second syllable that bears the accent, even if outside of composition this is not the case. Aspiration would thus be a consequence of stress as well as a demarcative trait, so that those words that lose stress in composition also lose aspiration (bil "to die" + herri "land, country" > ilhérri "cemetery"), whereas the ones that receive stress develop it (gau "night" + erdi "half" > gauhérdi "midnight"), with respect to, of course, only the first two syllables in the word ( $c f r$. e.gu.érdi "midday").

The impossibility in current varieties for there to be two aspirates in the same word has been related by Natural Phonology to restrictions of duration or time (see Hurch, 1987: 38), and one should search within the rhythm of articulation, in the one that determines the pronunciation of prototypical syllables, for the prosodic factor that deletes the double articulation of consonants that consume more time than usual (Igartua, 2001: 190). Nor may two aspirated voiceless stops go in the same word (Lafon, 1948: 56-57 and 1958: 90, Mitxelena, 1951: 542), or an $h$ and an aspirated stop. As Mitxelena (1977: 214) claims, the word type with a vocalic onset and an aspirated stop at the beginning of the second syllable is so widespread that we may think that its generalization implied the loss of many of the old initial aspirates. At any rate, there are some exceptions to the rule, as is the case of hurhándi "river" (< hur "water", "river" + handi "big"), hurméhe "ford" (< hur + mehe "thin", "narrow") in Arrueta (NB, EHHA). We assume that the transparency of the elements, that is, semantics, must have favored in this case the preserving of aspiration.

The loss of aspiration in peninsular Vasconia seems to have been completed by the 16th century, according to Igartua (2002: 379-380; 2011: 904-905) perhaps because a shift of the accent took place, since if aspiration is a consequence of accent and the accent does not change, it can not be explained why the former disappeared. According to this author, aspiration is better preserved in Souletin, a dialect that has a strong intensity accent. The problem with this view, in our opinion, is that it would have to be explained how come the Navarrese varieties that also have this kind of accent lost aspiration already centuries ago. Igartua (2002: 379-380 and 2011: 896, 904), drawing on Mitxelena's well-known theory, mentions contact with Aragonese, which lacked said sound, whereas the north-eastern varieties were in greater contact with Gascon, a fact that favored the preserving of aspiration.

But the strong accent of other western varieties was not lost at the same time as aspiration either. Hence this brings us to a dead end. One way to solve the problem, according to Igartua (ibid.: 381), is to consider that aspiration is a phonetic-prosodic trait that is tied to the root, which was first monosyllabic in Proto-Basque, but subsequently there would have been disyllabic roots in Aquitanian, due to the fact that these probably were complex forms, that is to say, not monomorphemic (ibid.: 384). The reshaping of the root would have given rise to changes in the distribution of aspiration. Names carrying two $h$ s in the Reja might indicate that each compound member kept their autonomy. 


\section{THE CONTRIBUTION OF TOPONYMY TO THE STUDY OF ASPIRATION}

Now we are going to present, schematically and drawing mostly on major Alavese toponymy ${ }^{27}$, our contribution to what has been said so far by the different authors who have dealt with the topic of aspiration. It is not necessary to note that the data that we show here are directly related to what has been exposed in the previous sections regarding the position in which aspiration can appear, the constraints that it is subject to, the time of its weakening and disappearance, etc.

6.1. Regarding the graphic problems concerning old data, it is noteworthy that in Alavese toponymy sometimes $k$ - and $-k$ - are documented instead of the later and wellknown variant with $b$ - or - $b$-: Carreluzea (1025), Arriluzea (1257), Arluzea (currently); Lekete (952), Lehete (1025), Lehet (1268), Lehete (1465), Lete (uninhabited town). In the first case we ignore whether the variant with $<\mathrm{k}>$ is related to the etymon *karrthat has been suggested for harri "stone", but it does not seem to be, due to a lack of parallel attestations. In the second, with regard to the first attestation Lekete and unless it is simply a reading mistake, we could be dealing with an attempt to represent in writing an aspirate consonant that sounded hard to the scribe's ears. It must be taken into account that the toponym Lehete, which still bears aspiration in the dialects that have not lost it, is repeatedly found throughout the Basque landscape, probably because it is an old appellative.

Furthermore, there is alternation between $-b$ - and $-b$ - in Arroiaha (1025), Erroiauee (1205), Arroyabe (1268), Arroiabe at present, and perhaps also in Mendibil (1025, reading by A. Ubieto, 1976), Mendivil (1025, García Andreva, 2010), Mendiuil (1257), Mendibil (1457 and nowadays). Concerning the second toponym, it seems as though we face a more palaeographic rather than phonologic problem, that is, a reading problem. In any case, and in our view, Mendiuil can be clearly read in this case (see now <http:// www.ehu.eus/galicano/>). Regarding the first, it is not clear to us whether we are dealing with a grapheme mix-up motivated by the nearness between the sounds that they represented, or whether it has phonological grounds, drawing from *Arroiabehe, "Erroiabehe.

All authors agree, on the other hand, in reading Gardellibi (1025), a name documented as Gardelegui (1135), currently Gardelegi, a fact that would indicate, as Hamaezaha (1025), Amezaga (1295), Ameçaga (1320, 1410), Ametzaga (at present) and Hurabagin (1025), Hurabain (1066), Hurabahin (1321), Urabain (currently) do, an alternation between - $h$ - and - $g$-. It seems to be a mere graphic matter, but we cannot be completely certain, since the voiced velar fricative and the also voiced fricative aspirate are near

27 But we do not exclude to mention major and even minor toponyms from other parts of the central and western Basque country. It must be borne in mind that when the reference is lacking, the onym in question has been taken from Salaberri Zaratiegi (2015). The date 1025 makes reference to the so-called «Reja de San Millán» comprised in El Becerro Galicano de San Millán de la Cogolla. See García Andreva (2010) in the references given at the end of this paper. 
from an articulatory and perceptive point of view. Cfr. Çulahabehetia and Çulahagoitia in 1413 (A, Paz, 2013: 155), Zulagabeitia and Zulagagoitia in the mid-19th century. Let it be reminded that what one gets in other varieties as abo "mouth", behor "mare", ehun "one hundred", lohi "mud" is ágo, begór, egún, lógi in some Navarrese dialects.

6.2. With respect to the diachrony of the topic, it has been believed that aspiration disappeared in the 13th-14th centuries, but in Alavese toponymy one finds $b$ until at least the 16th century. Let it be reminded that already in the 1940s Bähr (1948: 172) claimed, drawing on data (even though not all the data that he presents can be considered valid nowadays), that aspiration had been preserved in the southern dialects until 1600 CE: "It is a very remarkable fact that Basque displays or displayed the aspirate $h$ as well as voiceless aspirated plosives $(p h, t h, k h)$. Nowadays these are only preserved in the dialects on this side of the Pyrenees, whereas $h$ faded away by around 1600 AD among the varieties spoken in the Spanish Basque Country» ${ }^{28}$.

In Gipuzkoa we also have late data that seem to display such sound: Lohiola (literally "the mud hut" or "the mud iron works", Zestoa, 1380; Ayerbe \& Elorza, 2008: 11; the variant lacking $<\mathrm{h}>$ is attested in 1474, ibid.: 91), Iherategui, Yherategui ("(the) place / house of the mill", Getaria, 1394, ibid.: 36), Abunçebaso (along with Aunçebaso, probably "(the) forest of the goats"), Behengoechea, Vehengoechea ("the lowest house", "the lower house"), Çuhube (Zestoa, 1479, ibid.: 113-119, 146), Çacurhuvietachipia (and Çacurvbieta, Oiartzun, 1499; Irijoa \& Lema, 2011: 79-80), etc.

The problem that we are faced with here is the one regarding the character of the $\langle\mathrm{h}\rangle$, since very often we do not know for sure whether the mentioned grapheme is representing an aspirated sound or is a mere graphic addition whithout any phonic content. This seems to be the case in Olajabunliçardia "the ash grove of the iron works owner" (Zestoa, 1479; Ayerbe \& Elorza, 2008: 119), from olajaun "(the) iron works owner" and lizardia "the ash grove". In any case, the etymology of the place name in question is very helpful in order to determine the reality hidden under said $<\mathrm{h}>$. Another $<\mathrm{h}\rangle$ that seems to have a mere graphic character is the one in Helexalde (Altsasu, N, 1516; Pozuelo, 2010: 462) and Helexoste (Narbaxa, A, 1518; ibid.: 521), both of which are compounds containing a first member elexa "church". This is a loanword that ultimately comes from Latin $e c(c) l e s i a$, which does not display aspiration.

6.3. As we have seen above (second section), in the last centuries there has been a rule that restrains aspiration to the first two syllables of the word, but it did not apply either in Aquitanian, in the Reja de San Millán data or even in ensuing centuries: Adurzaha

28 «Sehr bemerkenswert ist die Tatsache, dass das Baskische sowohl den Hauchlaut $b$ wie behauchte Tenues $(p h, t h, k h)$ besitz $(s i c)$ oder besessen hat. Heute sind sie nur in den Dialekten diesseits der Pyrenäen erhalten, während $h$ in den im spanischen Baskenlande gesprochenen Mundarten etwa um 1600 verstummt ist». Concerning the phrase «diesseits der Pyrenäen» it must be taken into account that Bähr was looking at the Basque Country from Germany. 
(A, 1025), but Adurçaa, (1258, Martínez, 1974, II, 195); Goiahen (A, 1025), Goiahin (1156), Goyahiyn (1268), Goyahen (1456); Larrahara (A, 1025), Laraharia (1257, Rodríguez, 1989: 227), Larraharra (ca. 1275, ibid.: 304), Laraharra (1295, ibid.: 438), Larraharra (1510, Lema, 2007: 196); Larrahuri (A, 1312, Díaz de Durana, 1994: 13); Larrinçahar (A, 1467); Marahuri (A, 1325); Munniahin (A, 1025), Munyahin (1268), Munnahin (1326), Munahin (1332, 1351); Oçaheta, Ozaheta, Ocaheta, Oçaheeta, Hoçaheta (A, 1321, 1331, 1429, 1470); Ulquaherria, Urcaherria (A, 1421; Urcaerria in 1436), etc. We do not know the specific etymon for Larucahea, Laraçahea (Zurbao, A, 1519; Pozuelo, 2013: 309, 318); cfr., in any case, Elhorzahea in 1025 and Careaçahea in 1413 (Deredia, A, Paz, 2013: 155).

Also in La Rioja we find toponyms with an $b$ in the third or fourth syllable: Iraburi, Villa Irahuri (1082, 1106, ibid.: 305, 438), Moruhai, Moruvay, Muruaby, Murufay, Muruhai, Muruhabi, Muruhay, Muruvaby (ca. 1156, 1210, 1251, Ag. Ubieto, 1978: 31, 33, 86, 115), Semenohuri (1095, García Andreva, 2010: 385), Vermudohuri, Vermuduhuri $(1052,1095$, ibid.: 385,390$)$, etc. In this region there is a rather interesting toponym, Sajazarra, the name of a little village, attested as Saggazahar in 1075 (García Andreva, 2010: 403), Saiia Çaharra in 1275 (Rodríguez, 1989: 230) and still Sajaçaharra in 1366 (Pozuelo, 2007: 246-247), with a second member zaharra "the old (one)”.

In any case, it must be born in mind that in compounds, even at present, aspiration sometimes goes in the second syllable of the second member, by which the overall count can be the third or fourth: astelehén "Monday", bidéhandi "road", árgihástian "dawn", árraphésta "recurrence of the holiday", otsónahár "wildrose", zérüzahárra "break in the clouds", the last ones of which bear two accents (Arrueta, NB, EHHA).

6.4. Aspiration appears at the beginning of the word: Haizpilleta, Haiztara, Huriarte, Hurivarri (A, 1025), Halayça (A, 1257; Rodríguez, 1989: 218); Harizavalleta (A, 1025), Harizaballeta (1135), Harechavaleta (1258), Harrachavaleta (1381); Harrizavallaga (A, 1025); Hegilior (A, 1025), Heguileor (1257), Heguileor, Heguileorr, Heguillorr (1501); Hegiraz (A, 1025), Heguiraz (1156), Heguilaz (1200, 1205, 1308, 1379); Hiraszaeza (A, 1025), Herurez (1367), Hyrurez (1380), etc.

6.5. It can also appear in intervocalic position, at the onset of the second syllable: Ehari (A, 1025, 1066, 1135), Ehaly (1258), Ehali (1295); Uhulla (A, 1025), Uhula (1258, Martínez Díez, 1974, II, 195; 1320, Inurrieta, 1989: 41, 47), Uhulsarri, Ubusarri (1393, ibid.: 145, 147), Hubula (1429, Goicolea, 1998: 198), Uhula (1450, ibid.: 189, 191, 195), etc.

6.6. Some toponyms bear two hs: Hagurahin (1025, 1256, 1308), Hareizelheta (A, 1106, García Andreva, 2010: 950), Harhazua, Hascarzaha, Hillarrazaha (1025). Some bear even three: Harhahia (1025), Arhaya (1386), currently Araia. The fact that both members preserve $b$ in compounds might mean that each of them kept their autonomy (and their accent; see Mitxelena, 1977: 212): Harriolha, Hurizahar (1025). 
Also in La Rioja we find toponyms that display two aspirates: Arhaiburi (1104, cfr. the abovementioned Alavese Harhahia), Harbehea (ca. 1212, Ag. Ubieto, 1978: 86), and, likewise, probably Formazahar (1075, García Andreva, 2010: 403). In Gipuzkoa we find the transparent and due to its lateness surprising Yheraçaharra (Zestoa, 1479; Ayerbe \& Elorza, 2008: 148), which is documented together with Yheracarreta (ibid.: 133, 134), the place where a mill burnt down (eihera, eihara, the second of which currently has a variant ihára, meaning "mill”). Also Hetumeheta (1512, Zestoa - Errezil, ibid.: 234) is rather unexpected for the same reason. In any case, it is attested along with Etumeeta (1452, ibid.: 75), Etumeta (1512, ibid.: 231) and Hetumeta (ibid.: 232).

6.7. The heterosyllabic clusters l.h (Barolha, Galharreta, Gelhegieta, Mendiolha, Olhauarri, A, 1025, now Baroja, Galarreta, Egileta, Mendiola, Ollábarri or Ollábarre), n.h (Heinhu, 1025, Eguinno, 1062, at present Egino), r.h (Harhazua, 1025; Barfone, 978, Barhoa, 1025; Luperho, 1025; currently Arratzua, Barrón, Lupierro) come from l.h or $* L, * N$ and $* R$, which are fortis sonorants or are thus treated. Later Orolhen (and Orrollen, 1320; Pozuelo, 2010: 751, 754) and Alhana, Alhaña (1503, Pozuelo, 1998: $371,375)$ are documented in the same region.

The Riojan toponym Hatumanhuri (1073, García Andreva, 2010: 403) is worth mentioning. It is based on the personal name *Hatuman(i) (which is attested in sennor Alvaro Scemenoz de Atumani; consider as well Obtheman, Autemani, Mitxelena, 1976: 63; according to this author «even though this is not at all important in the current context, the anthroponym does not sound Basque. Perhaps one may claim that it has an Arabic appearance, if that may not be a mere admission of ignorance ${ }^{29}$ ). This name turned into Atoman in 1124 (Atomanori, Rodríguez, 1992: 138 ), whereby a reduction seems to have taken place: $-V n . h V->-V n . V-$ (or, through a change in syllable structure, $-V \cdot n V-)>-V . V$ - or $-V v$ - (perhaps a diphthong): Atumauri (1185, García Andreva, 2010: 1071), Hatomauri (1215, Rodríguez, 1979: 239), Atomauri (1257, Rodríguez, 1989: 224).

We might find the same change in the anthroponym Izahuri that Mitxelena (1976: 62) mentions and identifies with Villazán, that is to say, the "town of the one called Izán". This may match the toponym Izanotz (N, attested in 1269 as Yçanotz, Felones, 1982: 31; see Salaberri Zaratiegi, 2011: 51), with a likely base in *Izano, a doublet of the documented Izani (no date, García Andreva, 2010: 745; 1028, ibid.: 849; we could, however, turn to analogy), in the same way as the Riojan uninhabited town Velascuri (1551, Díaz Bodegas, 1998: 152), previously attested as Brascori villa (1089, García Andreva, 2010: 497), villa Blascori (1078, ibid.: 444), Blascuri (1189, Ag. Ubieto, 1978: 62) matches Beskoitze in Lapurdi, Berascoizcoac "the one from Beraskoi(t)z" (in the ergative case) in Leizarraga's work, Berascoïzco “from Berasko(i)tz” in Haraneder's.

29 «Aunque esto no tiene importancia alguna en el contexto actual, el antropónimo no suena a vasco. Acaso se podría decir que tiene aire árabe, si esto no fuera un mero reconocimiento de ignorancia». 
Velascuri, Brascori and Beraskoitz correspond also to Belascoáin (N), called Beraskoain in Basque. The problem we are faced with is that what we have found is the above-mentioned Irahuri, not Izahuri, but perhaps a more thorough search than ours may easily overcome this obstacle.

Without leaving La Rioja we find also Olhauri (1185, Ag. Ubieto, 1978: 58), Hollauri (1215, Rodríguez, 1989: 29 and 1551, Díaz Bodegas, 1998: 167), Olauri (1257, Rodríguez, 1989: 224), currently Ollauri, and Barharanburu (Bañares-Santurdejo, 1211; Ag. Ubieto, 1978: 83), etc. There is no need to note that these are exactly the same contexts in which aspiration occurs at present.

6.8. Often - $h$ - divides both members of a compound: Bagaduyhederra (A, 1416, Goicolea, 1998: 78; bagadui "beechwood" + eder "beautiful" + -a article), Çuma hurdina (along with Camahurdina, A, 1405, ibid.: 4; perhaps from zumar "elm" or zume "wicker" + urdin "bluish gray", "gray" + -a), Goseascobasahondua (A, 1456, Pozuelo, 2013: 46; "what lies next to the high forest", from goxeasko "upper", "higher" + basa"forest" + ondo "next to" + -a), Huriuarriharaca (A, 1257, Rodríguez, 1989: 219; Huribarri + Araka), Larrehurdina (B, 1485, Enríquez et al., 1994: 176; larre "meadow" + urdin + -a), Tellaheche (A, 1454, Pozuelo, 2013: 396; teila "rooftile" + etxe "house", that is to say, "(the) house covered by rooftiles" or less likely "(the) tiling workshop"), Uçain herreca (A, 1488, Paz, 2013: 242; "the brook of Uzain" and less probably "the leeches' brook"), Urrechatehostea (A, 1488, ibid.: 229; Urretxate "the narrow pass of the hazelnut tree" + oste "rear side" + -a), Varaça hondoa (A, 1418, Goicolea, 1998: 78; "what lies next to the vegetable garden", from baratza "vegetable garden", ondo "next to" and $-a$ article). It must be taken into account, however and concerning etxe and urdin, that according to Lakarra (2002: 431-432, 2015b: 358-359) the first is probably related to hertsi (root "her) "to close" and the second is derived from hur "water", with an etymological $h$ -

This also happens outside of Alava: in Zestoa (G) there is Aztihederra (1479, Ayerbe \& Elorza, 2008: 109) and in Oiartzun Aranhederra (1499, Irijoa \& Lema, 2011: 47). This $-h$ - is so widespread that it becomes difficult to believe it was not pronounced, even though in some cases like Treshadarretac in Oiartzun (G, 1499, Irijoa \& Lema, 2011: 23) it is complicated to think that it was pronounced. At present aspiration does not seem to be common in compounds, but aste áRte "Tuesday" in Hazparne (L) and asteharté in Landibarre (NB) have been registered in EHHA, from aste "week" + arte "between", even though this one is currently not perceived as a compound.

6.9. In a few cases etymological aspiration and aspiration that is motivated by composition coincide: Arechola heguya (Altzania - Urbia, 1416, Goicolea, 1998: 78; perhaps Aretxola "the oak [wood] cabin" + hegi "lengthy summit", "slope" + -a), Ascarçaharan (Sastegi, A, 1488; Paz, 2013: 230; askartza "maple tree forest" plus haran "valley"; cfr. 
Barreneco harana "the lower valley", Baxauri, A, 1420; Pozuelo, 1998: 77), Liabubieta (Oiartzun, G, 1499; Irijoa \& Lema, 2011: 119) ${ }^{30}$.

6.10. An $h$ marks the morpheme boundary, even though in some cases it could be etymological: Arbelgoihen (A, 1025), Arzanhegi (A, 1025), Azazaheta, Erroheta, Gazaheta, Ogueheta (A, 1025), Gastehiz (A, 1025). Here we would be dealing with an aspiration that has a demarcative function (see Igartua, 2001: 204, 2002: 375, 2011: 909). Manterola (2015), by contrast, claims that the -heta attested in 1025, including the aspirate, comes from the third-degree Basque demonstrative pronoun. This, of course, does not only happen in the Reja: Apoheta (A, 1416), Gomiz de Larrinhetago (BU, 1129, García Andreva, 2010: 1188, perhaps for Gomiz de Larrinhetaqo; cfr. Pedro Lozaquo, Sancio Goiquoa, LR, 1186, Ag. Ubieto, 1978: 59, and Acenar d'Azpilagaco, N, ca. 1110, Goñi, 1997: 129) and not only in Álava either: Arreteheta, Corteheta, Elcoheta, Iraheta, Yraheta, Yrameteheta (Zestoa, G, 1380, 1393, 1479; Ayerbe \& Elorza, 2008: 29, 113, 126, 143, 166).

6.11. In some toponyms the shift $-b->b$ - is clear: Arzanhegi $(1025)>$ Harçanegui (1257, Rodríguez, 1989: 217); Elhorriaga (1025) > Helorriaga (1331); Elhossu (1025) $>$ Helosu (1276), etc.

\section{FINAL REMARKS}

To conclude, and as a closing note, we would like to point out the importance of the detailed study of toponymy, and of onomastics in general, for the broader and better understanding of the history of Basque. By means of the publication of medieval documents we have increasing data, and it is essential to use them and to do so properly, in order to delve deeper into the as yet not completely enlightened corners of our language. It should be unnecessary to point out that the data provided by dialectology are essential for an adequate study of a topic such as aspiration, as well as that typology gives us a much broader perspective of this phenomenon.

30 This was an area located near a creek, and it is therefore reasonable to believe that we are dealing with $l i(b) a$-, which is the composition variant of libo "linen" $+(b) u(r)+b i+-e t a$, that is to say, "the two creeks" junction next to which linen is cultivated/washed". 


\section{ABBREVIATIONS}

A: Araba / Álava.

B: Bizkaia / Biscay.

BU: Burgos.

EHHA. See Academy of the Basque Language.

G: Gipuzkoa.

L: Lapurdi / Labort, Labourd.

LR: La Rioja.

N: Nafarroa / Navarra / Navarre.

NB: Nafarroa Beherea / Baja Navarra, Basse-Navarre / Low Navarre.

Z: Zuberoa / Sola, Soule.

\section{REFERENCES}

Academy of The Basque Language, Euskararen Herri Hizkeren Atlasa. It can be consulted in <www.euskaltzaindia.eus/ehha $>$.

Ayerbe, M. ${ }^{a}$ R. \& Elorza, J., 2008, Archivo Municipal de Zestoa (1338-1520), Donostia/San Sebastián, Eusko Ikaskuntza, «Fuentes documentales medievales del País Vasco", 136.

BäHr, G., 1948, Baskisch und Iberisch, Baiona: Eusko Jakintza, 2. There exists a Spanish version translated in 2016 by Joakin Gorrotxategi with the collaboration of José María Vallejo and Carlos García Castillero. See <https:// web-argitalpena.adm.ehu.es/listaproductos.asp?IdTopics>.

Camino, I., 2015a, "Oztibarreko mintzoaz eta haren lexikoaz», Fontes Linguae Vasconum, 119, 5-60.

— 2015b, «Amiküzeko heskuararen egitura lektala», in I. Epelde (ed.), Euskal hizkera eta dialektoak gaur egun, special issue of Lapurdum, 27-79.

Díaz Bodegas, P., 1998, Libro de visita del licenciado Martín Gil, Logroño, Diócesis de Calahorra y la Calzada - Logroño.

Díaz de Durana, J. R., 1994, Álava en la Baja Edad Media a través de sus textos, Donostia/San Sebastián, Eusko Ikaskuntza, «Fuentes documentales medievales del País Vasco», 54.

Elorza, J. C., 1967, «Ensayo topográfico de epigrafía romana alavesa», Estudios de Arqueología Alavesa, 2, 119-185.

Enríquez, J. et al., 1994, Colección documental del Archivo Municipal de Orduña (1271-1510). Tomo I, Donostia/San Sebastián, Eusko Ikaskuntza, «Fuentes documentales medievales del País Vasco», 52.

Felones, R., 1982, "Contribución al estudio de la iglesia navarra del siglo xiII: el libro del rediezmo de 1268 (II). Transcripción e índices», Príncipe de Viana, 166-167, 623-713.

García Andreva, F., 2010, El becerro galicano de San Millán de la Cogolla. Edición y estudio; Aemilianense, San Millán de la Cogolla, Cilengua. Instituto Orígenes del Español. Now it is available on-line: <http://www.ehu.eus/ galicano/>. 
Gavel, H., 1920, Éléments de phonétique basque, Revista Internacional de Estudios Vascos, 12.1.

Goicolea, F. J., 1998, Archivo Municipal de Salvatierra-Agurain. Tomo II. (14011450), Donostia/San Sebastián, Eusko Ikaskuntza, «Fuentes documentales medievales del País Vasco", 83.

GoÑı, J., 1997, Colección Diplomática de la Catedral de Pamplona. 829-1243, Pamplona/Iruñea, Gobierno de Navarra.

Gorrotxategi, J., 1984a, Onomástica indígena de Aquitania, Bilbo/Bilbao, UPV/ EHU.

- 1984b, «Acerca de Helasse teónimo indígena atestiguado en Miñano Mayor (Álava)», Veleia, 1, 261-265.

- 1995, «Los Pirineos entre Galia e Hispania: las lenguas», Veleia, 12, 181-234.

- 2002, "Las lenguas de los Pirineos en la Antigüedad», Els substrats de la llengua catalana: una visió actual, Barcelona, Societat Catalana de Llengua y Literatura, Institut d'Estudis Catalans, 75-101.

- 2015, «Akitaniera eta euskara», in B. Fernandez and P. Salaburu (eds.), Ibon Sarasola, Gorazarre. Homenatge, Homenaje, Bilbo/Bilbao, UPV/EHU, 291-302.

Grimm, J., 2009 [1848], Geschichte der deutschen Sprache, Volume 1, Cambridge, Cambridge University Press.

Hualde, J. I., 2015, «Dialektologia dinamikoa», in I. Epelde (ed.), Euskal hizkera eta dialektoak gaur egun, special issue of Lapurdum, 125-153.

Hurch, B., 1987, «On Aspiration. With Special Reference to Basque», in P. Salaburu (ed.), Euskal morfosintaxia eta fonologia eztabaida gaiak, Bilbo/Bilbao, UPV/EHU, 31-52.

- 1988, Über Aspiration. Ein Kapitel aus der natürlichen Phonologie, Tübingen: Gunter Narr Verlag, «Ergebnisse und Methoden moderner Sprachwissenschaft», 23.

IgARtua, I., 2001, "La aspiración en vasco: ensayo tipológico y diacrónico", Anuario del Seminario de Filología Vasca «Julio de Urquijo», 35.1, 185-213.

- 2002, «Euskararen hasperena ikuspegi tipologiko eta diakronikotik», in X. Artiagoitia, P. Goenaga and J. A. Lakarra (eds.), Erramu Boneta. Festschrift for Rudolf P.G. de Rijk, Bilbo/Bilbao, UPV/EHU, «Suplementos del Anuario del Seminario de Filología Vasca "Julio de Urquijo"», 44, 367-390.

— 2006, «Del origen de la aspiración como elemento morfofonológico en vasco», in J. A. Lakarra and J. I. Hualde (eds.), Studies in Basque and Historical linguistics in memory of R. L. Trask, Anuario del Seminario de Filología Vasca «Julio de Urquijo», 40.2, 519-530.

- 2008a, «La aspiración de origen nasal en la evolución fonológica del euskera: un caso de rhinoglottophilia», Anuario del Seminario de Filología Vasca «Julio de Urquijo», 42.1, 171-190.

—2008b, "Algún paralelo tipológico más para la $h$ vasca de origen nasal», Anuario del Seminario de Filología Vasca "Julio de Urquijo», 42.2, 353-357.

- 2011, "Historia abreviada de la aspiración en las lenguas circumpirenaicas», in A. Sagarna, J. A. Lakarra and P. Salaberri (eds.), Pirinioetako hizkuntzak: 
lehena eta oraina, Bilbo/Bilbao, Real Academia de la Lengua Vasca, «Iker», 26, 895-918.

- 2015, «Diachronic effects of rhinoglottophilia, symmetries in sound change, and the curious case of Basque", Studies in Language, 39.3, 635-663.

IÑurrieta, E., 1989, Colección diplomática del Archivo Municipal de Salvatierra (1256-1400), Donostia/San Sebastián, Eusko Ikaskuntza, «Fuentes documentales medievales del País Vasco", 18.

IrijoA, I \& Lema, J. A., 2011, Documentación medieval del Archivo Municipal de Oiartzun. I. Libros de estimaciones fiscales de vecinos y bienes raices (1499-1520), Donostia/San Sebastián, Eusko Ikaskuntza, «Fuentes documentales medievales del País Vasco», 143.

Jimeno, J. M. ${ }^{\text {, }, 1968, ~ D o c u m e n t o s ~ m e d i e v a l e s ~ a r t a j o n e s e s ~(1070-1312), ~ P a m p l o n a / ~}$ Iruñea, Diputación Foral de Navarra, Institución Príncipe de Viana.

Kamino, P. \& Salaberri, P., 2007, Luzaideko Euskararen Hiztegia, Pamplona/Iruñea, Gobierno de Navarra - Real Academia de la Lengua Vasca, «Mendaur», 3.

- (in preparation), Luzaideko Euskararen Azterketa.

LAFON, R., 1948, «Remarques sur l'aspiration en basque», Mélanges offertes à M. le Professeur Henri Gavel, Toulouse, Édouard Privat \& $\mathrm{C}^{\mathrm{ie}}$, 55-61.

- 1958, "Contribution a l'étude phonologique du parler basque de Larrau (HauteSoule)», in D. Catalán (ed.), Miscelanea homenaje a André Martinet, volume 2, Canarias, Universidad de La Laguna, 77-106.

LAKARra, J. A., 1997a, «Euskararen historia eta filologia: arazo zahar, bide berri», ASJU, 31.2, 447-535.

- 1997b, "Gogoetak aitzineuskararen berreraiketaz: konparaketa eta barneberreraiketa», Anuario del Seminario de Filología Vasca "Julio de Urquijo», 31.2, 537-616.

- 2002, «Etimologiae (proto)uasconicae LXV», in X. Artiagoitia, P. Goenaga and J. A. Lakarra (eds.), Erramu Boneta. Festschrift for Rudolf P.G. de Rijk, Bilbo/ Bilbao, UPV/EHU, «Suplementos del Anuario del Seminario de Filología Vasca "Julio de Urquijo"», 44, 425-442.

$-2009, \ll h_{3}>h_{1}, " h_{2}>h_{1}$ eta horiei datxezkien zenbait fenomenoz», Lapurdum, 13, 211-231.

— 2010a, «Adabakiak/h/-aren balio etimologikoaz», R. Etxepare, R. Gómez and J. A. Lakarra (eds.), Beñat Oihartzabalen omenez / Festschrift for Bernard Oyharçabal, Anuario del Seminario de Filología Vasca «Julio de Urquijo», 43.1-2, 565-596.

- 2010b, «Haches, diptongos y otros detalles de alguna importancia: notas sobre numerales (proto)vascos y comparación vasco-ibérica (con un apéndice sobre hiri y otro sobre bat-bi)», Veleia, 27, 191-238.

— 2011, "Gogoetak euskal dialektologia diakronikoaz: euskara batu zaharra berreraiki beharraz eta haren banaketaren ikerketaz», in I. Epelde (ed.), Euskal dialektologia: lehena eta oraina, Bilbo/Bilbao, UPV/EHU, "Suplementos del Anuario del Seminario de Filología Vasca "Julio de Urquijo"», 69, 155-241.

— 2012, «Teoría de la raíz monosilábica y reconstrucción del protovasco: algunos aspectos y consecuencias», in J. A. Lakarra, J. Gorrochategui and B. Urgell 
(eds.), 2nd Conference of the Luis Michelena Chair, Vitoria-Gasteiz, UPV/ EHU, 263-286.

- 2015a, «Saratsola eta (aitzin)euskar(ar)en geruzak», in B. Fernandez and P. Salaburu (eds.), Ibon Sarasola, Gorazarre. Homenatge, Homenaje, Bilbo/Bilbao, UPV/EHU, 419-439.

- 2015b, «Hiru hasperen laboro», in M. J. Ezeizabarrena and R. Gómez (eds.), Eridenen du zertaz kontenta: sailkideen omenaldia Henrike Knörr irakasleari (1947-2008), Bilbo/Bilbao, UPV/EHU, 349-378.

Lema, J. A., 2007, Colección Documental del Archivo Municipal de Bergara. III. Fondo Iturbe-Eulate (1401-1520), Donostia/San Sebastián, Eusko Ikaskuntza, «Fuentes documentales medievales del País Vasco», 134.

Manterola, J., 2015, Euskararen morfologia historikorako: artikuluak eta erakusleak / Towards a history of Basque morphology: articles and demonstratives, unpublished dissertation (UPV/EHU).

Martínez, G., 1974, Álava Medieval, Vitoria-Gasteiz, Diputación Foral de Álava, Consejo de Cultura, two volumes.

- 1998, Colección documental del Monasterio de San Pedro de Cardeña, Burgos, Caja de Ahorros y Monte de Piedad del Círculo Católico de Obreros de Burgos.

Meyer-LüBKe, W., 1924, «Der Schwund des zwischensilbigen $n$ im Baskischen», Revista Internacional de Estudios Vascos, 15.2, 209-238.

Mitxelena, K., 1950, «De fonética vasca. La aspiración intervocálica», Boletín de la Real Sociedad Vascongada de Amigos del País, 6, 443-459.

- 1951, «De fonética vasca. La distribución de las oclusivas aspiradas y no aspiradas», Boletín de la Real Sociedad Vascongada de Amigos del País, 7, 539-549.

— 1954, «De onomástica aquitana», Pirineos, 10, 409-455.

- 1957-58, "À propos de l'accent basque », Bulletin de la Société Linguistique de Paris, 53, 204-233.

- 1961, «Los nombres indígenas de la inscripción hispano-romana de Lerga (Navarra)», Príncipe de Viana, 82/83, 65-74.

- 1976, «Onomástica y población en el antiguo reino de Navarra: la documentación de San Millán», XII Semana de Estudios Medievales. 1974, Pamplona/ Iruñea, Diputación Foral de Navarra - CSIC, 49-71.

- 1977, Fonética Histórica Vasca, Donostia/San Sebastián, Diputación de Gipuzkoa, Publicaciones del Seminario «Julio de Urquijo», 2nd edition.

O’Brien, J., 2010, «Debuccalization and supplementary gestures». Paper published online; see <http://jeremypobrien.nfshost.com/papers/obrien_qe.pdf >.

PAz, A., 2013, El monasterio de Barría. Historia y documentos (1232-1524), Bilbo/ Bilbao, UPV/EHU, «Inéditos de Historia», 7.

Pozuelo, F., 1998, Documentación de la Cuadrilla de Campezo: Arraia Maeztu, Bernedo, Campezo, Lagran y Valle de Arana (1256-1515), Donostia/San Sebastián, Eusko Ikaskuntza, «Fuentes documentales medievales del País Vasco», 88.

- 2007, Archivo Municipal de Salinas de Añana - Gesaltza. Documentos (14001517), Donostia/San Sebastián, Eusko Ikaskuntza, «Fuentes documentales medievales del País Vasco», 131. 
-2010, Archivo Municipal de Salvatierra - Agurain. Tomo IV (1501-1521). Apéndice 1259-1469, Donostia/San Sebastián, Eusko Ikaskuntza, «Fuentes documentales medievales del País Vasco", 141.

- 2013, Colección Documental de la Cuadrilla Alvesa de Zuia. II. Archivos Municipales de Arratzua-Ubarrundia y Legutio, Donostia/San Sebastián, Eusko Ikaskuntza, "Fuentes documentales medievales del País Vasco», 149.

Rodríguez, I., 1979, Colección Diplomática Medieval de La Rioja. Tomo III: Documentos (1168-1225), Logroño, Servicio de Cultura de la Diputación de La Rioja.

- 1989, Colección Diplomática Medieval de La Rioja (923-1225). Tomo IV: Documentos siglo XIII, Logroño, Gobierno de La Rioja, Instituto de Estudios Riojanos.

- 1992, Colección Diplomática Medieval de La Rioja (923-1225). Tomo II: Documentos (923-1168), second edition, Logroño, Gobierno de La Rioja, Instituto de Estudios Riojanos.

Salaberri Zaratiegi, P., 2011, «De toponimia vasco-pirenaica: sobre el sufijo -otz, -oz(e)», Nouvelle Revue d'Onomastique, 53, 33-63.

- 2015, Araba/Álava. Los nombres de nuestros pueblos, Bilbo/Bilbao, Diputación Foral de Álava - Real Academia de la Lengua Vasca, «Izenak», 5.

Schuchardt, H., 1906, Baskisch und Romanisch: Zu de Azkues baskischem Wörterbuch, Halle, Max Niemeyer.

- 1908, Die iberische Deklination, Wien.

Trask, R. L., 1997, The History of Basque, London - New York, Routledge.

Ubieto, A., 1976, Cartulario de San Millán de la Cogolla (759-1076), Valencia, Instituto de Estudios Riojanos-Monasterio de San Millán de la Cogolla-Anúbar Ediciones.

Ubieto, Ag., 1978, Cartularios (I, II y III) de Santo Domingo de la Calzada, Zaragoza, «Textos Medievales», 56.

Uhlenbeck, C. C., 1947, «Les couches anciennes du vocabulaire basque», Eusko-Jakintza, 1, 543-580.

VelazA, J., 1992, «El teónimo de las inscripciones de Barbarin (Navarra): problemas epigráficos y de interpretación», Príncipe de Viana, 196, 365-369. 


\section{ABSTRACT}

\section{An introduction to Basque aspiration: the contribution of onomastics}

In this article the authors first of all show the positions in which aspiration can appear within the word in Basque. Hereafter they explain which restrictions this sound is subject to and, after touching on the views of the few linguists for whom aspiration is not etymological and considering its non-random character as established, they make a list of the sources aspiration comes from. Subsequently they discuss its loss and consider to what extent the major Alavese toponymy, which is rich in $h s$, agrees or disagrees with the current data and with the various authors' claims. A number of historical toponyms from Gipuzkoa and La Rioja that bear the grapheme $<\mathrm{h}>$ are likewise taken into consideration. Finally, as a conclusion, the possibility is referred to of encompassing most of the developments that converge in aspiration in Basque into one and only phenomenon, as well as pointing out the importance of the use of onomastic, dialectal and typological data for the study of our language.

Keywords: aspiration; deaspiration; Basque toponymy; phonology; typology; history of the Basque language.

\section{RESUMEN}

\section{Introducción a la aspiración en euskera: la contribución de la onomástica}

En este artículo los autores muestran en primer lugar cuáles son las posiciones en las que la aspiración puede aparecer, dentro de la palabra, en euskera. A continuación explican a qué restricciones está sujeto dicho sonido y, tras mencionar la opinión del contado número de lingüistas para quienes no es etimológico y dar por establecido el carácter no adventicio del mismo, hacen un listado de las fuentes de las que procede. Posteriormente, hablan de su pérdida y examinan primero en qué medida la toponimia mayor alavesa medieval rica en hs está de acuerdo o en desacuerdo con los datos actuales, y después con lo dicho por los distintos autores. Se toman en cuenta, igualmente, algunos topónimos riojanos y guipuzcoanos históricos provistos del grafema $<\mathrm{h}>$. Finalmente, como conclusión, se cita la posibilidad de englobar la mayoría de las evoluciones que convergen en la aspiración vasca en un mismo y único fenómeno, y se menciona la importancia de la utilización de los datos onomásticos, dialectales y tipológicos para el estudio de nuestra lengua.

Palabras clave: aspiración; desaspiración; toponimia vasca; fonología; tipología; historia de la lengua vasca. 


\section{LABURPENA}

\section{Euskal hasperenerako sarrera: onomastikaren ekarpena}

Lan honetan egileek, lehenik, euskal aspirazioa hitzaren esparruan zein lekunetan ager daitekeen erakusten dute. Ondoren, aipatu soinuak dituen murrizketak azaltzen dituzte eta, euskararen hasperena etimologikoa ez dela uste duten hizkuntzalari bakanen iritziak eman eta gero, hasperenaren iturriak zerrendatzen dituzte. Jarraian aspirazioaren galeraz hitz egiten dute, eta $h$ franko erakusten dituen Arabako Erdi Aroko toponimia nagusia egungo erabilerarekin eta autoreek esan dutenarekin zer neurritan datorren bat aztertzen dute. Aintzat hartzen dira, orobat, $\langle\mathrm{h}\rangle$ duten Errioxako eta Gipuzkoako zenbait leku izen zahar. Azkenik, ondoriotako, aspiraziora daramaten bilakaera guztiak gertakari bakartzat hartzeko dagoen aukera aipatzen da, eta gure hizkuntzaren ikerketarako onomastika, dialektologia eta tipologia datuen azterketak duen garrantzia nabarmentzen.

Gako hitzak: hasperena; hasperena galtzea; euskal toponimia; fonologia; tipologia; euskararen historia. 
ISSN: 0046-435X ISSN-e: 2530-5832 